\title{
Successful Practices in Mathematics in the End of Elementary School
}

\author{
Danilene Donin Berticelli1, Neuza Bertoni Pinto², Poliana Migliavacca ${ }^{3}$ \\ ${ }^{1}$ Department of Engineering and Exact, Federal University of Paraná, Palotina, Brazil \\ ${ }^{2}$ Post-Graduate Program in Education, Catholic University of Paraná, Curitiba, Brazil \\ ${ }^{3}$ Paraná Education Department, Palotina, Brazil \\ Email: danilene@agrocelli.com.br
}

How to cite this paper: Berticelli, D. D., Pinto, N. B., \& Migliavacca, P. (2016) Successful Practices in Mathematics in the End of Elementary School. Creative Education, 7, 2504-2514.

http://dx.doi.org/10.4236/ce.2016.716237

Received: September 20, 2016

Accepted: October 22, 2016

Published: October 25, 2016

Copyright (c) 2016 by authors and Scientific Research Publishing Inc. This work is licensed under the Creative Commons Attribution International License (CC BY 4.0).

http://creativecommons.org/licenses/by/4.0/ (c) (i) Open Access

\begin{abstract}
Nowadays, professors are frequently challenged to develop new teach methods while confronting our complex society. This paper exemplifies how mathematic teachers are dealing with the existing challenges. The goal of this review is to illustrate the successful pedagogical practices from five mathematic teachers working in three different elementary schools in Brazil. The focus was to comprehend the teachers' conception about mathematics and its teaching. The study showed the teachers' commitment with the students' learning, with the studied themes contextualization, with the students' motivation and mathematics knowledge construction. We also could see the teachers' concern about their own professional development. The teachers pointed some breaks with memorize education, when indicated the group work practice, where the students are challenged to reason and discuss hypotheses with the classmates. It also shows that successful practices stem forms the involvement of the teacher with the improvement of his own pedagogic practice, learning in the practice the teaching art.
\end{abstract}

\section{Keywords}

Mathematics Education, Teachers Conceptions, Successful Practices

\section{Introduction}

The complexity of the present society has put new challenges to the teachers, which needs to give effective answers to the social requirements that are constantly changing. In this direction, teacher has worried about seeking new knowledge to develop new skills for what his teaching activities reach the professional success that is required for the new times in terms of warranty of effective learning from the students. 
Generally, the researches on teacher degree, specially the one aimed in understanding teacher's practices, contribute to the renewal of education. However, not always the results arrive to the knowledge of the most interested, the basic education teachers. In this direction, we highlight the importance of giving opportunity to the "break of break" suggested by Santos (1989), the possibility of investigate the transition from "common sense" to the "scientific production" and that this production returns like a "elaborated common sense", accessible to the educators.

In the actual educational scenario of Brazil, it seems to have a big concern from Math teacher with the teaching methods and a relentless pursuit for courses of continuing education. However, it perceives that, despite the teacher being in constantly innovating his practices, this investment has not guaranteed a good academic achievement from the students. Although of the advances in the researches related to the new methodologies to the Math teaching, the teacher not always gets to incorporate this to his practices and propitiates new math experiences to the students. In the classroom, we have a great number of unmotivated students or with learning disability, what suggests that the teachers' practices didn't release of the old conception and exclusive models that permeated, over the history, the math teaching and learning in school. The Math teacher seems to be "tied" and worried about winning the program ${ }^{1}$, with difficulties to articulate the subjects with the methodology in the process that can favor the social student's insertion, developing his potential and his participation more effective in the complex actual society.

Of course, we can't generalize these statements. It is known that numerous of Math teachers are facing these challenges and want to invest in new ways of teaching Math using the actual research to seek out equating the troubles put for the new times.

The intent of the present subject is to contribute to the improvement of quality of Math teaching in the Elementary school and sharing the achievements, we can collaborate with colleagues that work in this knowledge area. It's a research related to the concern of the researcher, throughout the teaching career, with the ways of teaching and learning the math. In this article, we will discuss the characteristics of the pedagogic practices in Mathematics that can be considered successful in the end of Elementary School, bringing the vision of some teachers. Which are the characteristics of the successful practices of teachers that give lessons of Mathematics in the end of Elementary School? What differential do these teachers present in their teaching practices? This article sought, therefore, to investigate the successful pedagogic practices adopted for Math teachers of $5^{\text {th }}$ to $8^{\text {th }}$ grader $\left(6^{\text {th }}\right.$ to $9^{\text {th }}$ grader) of Elementary School that acts in schools of Brazil ${ }^{2}$.

\section{Objectives}

The objective was to understand the characteristics of successful pedagogic practices in

${ }^{1}$ Winning the program means to teach all the preview subject to that grader.

${ }^{2}$ This paper is a part of a concluded investigation Berticelli, Danilene Donin. Successful practices in Mathematics in the end of Elementary School. Master Degree. Catholic Pontifice University of Paraná. Curitiba, 2012. 
Math in the end of Elementary School from authors who study the new conceptions that guide the teaching practices and from the Nationals Curricular Parameters (PCNs), document used as theoretical framework in the teaching institutions.

To characterize the successful practices, we sought to illustrate what the Nationals Curricular Parameters consider as successful pedagogic practices to the Math subject to the end of Elementary School. We also analyzed the characteristics of the pedagogic practices of Math teachers considered successful to the principal. To complete we identified similarities and differences between the proposed by Nationals Curricular Parameters and what the interviewed teachers said about the successful pedagogic practices. Considering that the teacher has the fundamental role in the process of teaching and learning and being him the main responsible from the conduction of the subject, which teaches, it is up to the teacher the assignment of teaching the content. Tardif (2010, p. 31) says that "a teacher is, before everything, someone that knows something and whose function consists in transmitting this knowledge to others". That is why; it is believed that one of the objectives of the teacher is to create conditions that can enable the learning of knowledge for the students. The art of teaching is a challenge to the teacher, because he (she) has to create, to recreate, to transform, to innovate to enable the students to understand and assimilate the subjects.

In this paper we sought to dialogue with some authors who have already developed studies about the teacher and his practice. It is believed that the school wouldn't have meaning without the teacher, as stated by Cunha (1989, p. 25) "it is impossible to ignore that without the teacher you do not have the school and, consequently, it is fundamental to deepen studies about him". Zeichner (1993) affirms that the teachers are theory and knowledge source, according to him, "the teachers are not just people who have a practice, in the narrow sense, but people that produce knowledge about education and who influence policies".

In a teaching practice compete a lot of knowledge, conceptions, beliefs, attitudes, values that are the teacher's knowledge. It is important to comprehend and to identify the knowledge that the teacher uses when he does the mediation of the student's learning. How the teacher appropriates the knowledge, if he considers the knowledge done and finished, if he has a dialogue with the students about this, if it is just transferred from the teacher to the students or if the teacher considers the knowledge of the student himself carries and produce based on the references that are given to him.

To teach the teacher mobilizes a lot of actions that are moved by his knowledge about the subject, didactic and pedagogical, knowledge that results from a lot of studies and the knowledge of his professional and personal formation. To teach the teacher acts on another being. Tardif (2010, p. 13) refers to teacher's knowledge as a social knowledge and says that "teaching is to act with other humans; it's to know how to act with other humans who know I teach them; it's to know I teach to other humans that know I'm a teacher". According to the author, the teacher's knowledge is produced socially and it is influenced by transformations of many groups. It's a social knowledge because it acts in person in training and with an objective of transforming, educating and in- 
structing the students. The teacher's knowledge is

"A process in construction over the course of a professional career, in which the teacher learns progressively to dominate his working environment, at the same time that he inserts himself into it and internalizes by rules and actions that makes an integral part of his 'practice consciousness" (Tardif, 2010: p. 14).

Considering that teachers are the main hosts of the curriculum proposals, the aim is to comprehend the aspects of the teaching action that stand out and produce good results in the teaching and learning Math process.

Regarding that the subject do not comprehend just the contents to be taught, but, according to Chervel (1990), mainly the process of teaching and learning that involves them, in this study, we sought to analyze the practices that stand out in the Math teaching. Which are the characteristics of a methodology considered more assertive, fruitful and favoring of the improvement of the student's learning?

Paulo Freire (1996) does some considerations about the "teaching" task. Analyzing in this perspective that to teach it is necessary pedagogic knowledge, Freire says us that "to teach is not to transfer knowledge, but create possibilities to its production or its construction". The author complements saying that "who teaches learn on teaching and who learn teaches on learning". This idea is strengthen by Tardif (2010) when he says that the teacher's knowledge it's social, when he puts in a direct relation the subject with his object, the knowledge can be produced collectively.

To the author, teaching is not something that happens emptily. The learning just happens when someone really learns. To teach, the teacher is challenged to develop a lot of abilities. You can't teach just contents. You also teach to think critically, to ratiocinate, to systematize, to create, etc., so the teacher must be always seeking, inquiring, intervening, educating, learning, communicating.

To put the teacher in front of himself and instigating him to think about his own role, his image, his practices, his concepts, his conception about the teaching and learning has been a valuable practice that can resign the teaching action, invest in his own professional development and specially review his beliefs and conceptions about the teaching and learning process. Freire says that

"In the ongoing teacher's formation, the essential moment is the critical reflection about the own practice. It is thinking critically today or yesterday practices that we can improve the next practice" (Freire, 1996: p. 39).

Considering teaching as an extremely complex activity, we also consider what Nóvoa (2009: p. 12) says, "Knowing to lead someone to the other margin, the knowledge, is not what everybody can reach.” and also what says Tardif (2010) in relation of teacher's task

"[...] one of the teachers objectives is to create conditions to enable the learning of the knowledge by the students, in an interactive context with them, the subject management makes a truly pedagogic challenge. The teacher's task consists, 
roughly, in transforming the subject that teaches in something that the student can comprehend and assimilate. So, this task is essentially pedagogic [...] It is true that the pedagogic knowledge to be thought can't be separated of the subject content. However, to know well the subject that he will teach is just one of the necessary conditions, and not the only one, of the pedagogic work" (p. 120).

The teacher's successful pedagogic practices, specifically in Math, were the north of this investigation.

The mediation of the social relation among teacher-student-knowledge happens throughout pedagogic practices. This relation is done in context by the social actors that make it up and suffer the influence or the way to be, to act and to think the social group evolved.

Cunha (1989) delimits the pedagogic practice as being the description of the teacher's daily in the preparation and implementation of its teaching.

According to this author, a lot of factors interfere in the "good teacher's" pedagogic practices. The pleasure of being in the classroom is one of the factors that influences in the teacher's making. The positive experience with the teaching gives back the taste of teaching. When it is installed an empathy between the parts, the teachers recognize that they learn a lot with the students, both in the sense of making the knowledge that is put in collective improve and in the improvement of relations. Her research points that the teacher is the great articulator of the learning process that happens with the students, he must be able to achieve all the efforts to the students learn.

The research also points that the action of the students in the classroom is likewise a factor that influences in the pedagogic practice. "The space of the classroom is for the students and must be occupied by them" (Cunha, 1989: p. 96).

To happen the learning is indispensable that the teacher establishes a good relation with the knowledge. It is a relation of affection between the teacher and his subject. We only can teach something we like. We only can charm the students when we are delighted by what we do. It's because of this that the relationship between the teacher and his subject is essential. "It seems that nobody can teach well something, if he can't answer himself about the goal of the knowledge deepened" (Cunha, 1989: p. 97). According to this same author, this relationship is important, because if neither the teacher can see the meaning in what he teaches, what will be left for the student?

The pedagogic practice is the way used by the teacher to the student act intellectually forward the content. It is important that the knowledge is created and recreated by the students and teachers in the classroom. The knowledge production in a collective form can take the student to act, to a critical reflection, to curiosity, to the demanding questioning, to the unrest and the uncertainty. How were this factor and other factors present in the pedagogic practices of Math teachers that participate of this research?

Van der Maren (1990: 2024 apud Tardif, 2010) describes the context of the pedagogic action and the necessary skills

It [the educative situation] is defined by eight following aspects: 1) one person 
(adult) supposedly endowed with knowledge 2) is regularly in contact 3) with a group 4) of people (children) that must be learning 5), and whose presence is mandatory 6), to teach them 7) a subject socially determined 8) by a series of decisions took in emergency situations (pp. 209-210)

The configuration of this professional profile of the teacher suggests some necessary abilities to teaching, among others, the ability to assimilate a pedagogic tradition transformed in habits, routines and craft tricks; the ability to built a cultural competence provides from a common culture of the daily knowledge shared with the students; the ability to discuss with them and to do assert his point of view; the ability to express with authenticity before them; to manage a class strategically in order to reach learning objectives, besides the ability to identify some behavior and to modify it to a certain extent.

\section{Methodology}

The research is a way to produce knowledge. A new knowledge that can advance something has already been studied. This is a work up to the researcher, who ends involving himself in a personal way with the subject, being necessary a self-study, creativity, rigor and determination. In the case of a teacher researcher, the research has a feature to possibility the teacher have a critical reflection about his actions, about his practice, so it can promote a better articulation between practice and theory.

Making a dialog with authors like Richardson (1999), Patton, (1986), Alves (1991), Bogdan and Biklen (1994) we chose the qualitative approach seeking to characterize the successful pedagogic practices once that this method attempt to a detailed comprehending of the meanings and characteristics of the situation by subjects, instead of production quantitative steps of characteristics or behaviors. In the qualitative approach, it seeks to understand the nature of a social phenomenon.

Patton (1986) indicates three essential characteristics in the qualitative studies: the holistic vision, where the comprehension of the behavior's or event's meanings is just possible in comprehending the interrelationships that comes from a specific context; the intuitive approach, that can be defined as the one in which the researcher sets forth freer observations, letting that the interested dimensions and categories gradually emerge, during a process of data and analysis collected; and the naturalistic investigation, in which the researcher's intervention in the context is reduced to the minimum.

Generally the studies that use this approach can describe the complexity of a special problem, analyze the interactions of certain variables, comprehend and rank dynamical process lived for some social groups, contribute in changing process of some special group, and enable, in a greater level of depth, the understanding of some particularities of the individual behaviors.

In this paper we analyzed two different kind of sources: written and oral. To the written sources we used the National Curriculum Guidelines (PCNs), student's notebooks, teacher's teaching plans, teacher's notes, among others that were necessary to catch up the research objectives. 
Considering that the goal of the research was to deepen and verify sources, we resort to oral sources using the interview technique. The interview enabled to obtain information from the interviewers: in personal and professional order. The oral sources was constituted in the depositions from five Math teachers ${ }^{3}$, indicated as "successful" for the principals from three teaching institutions of Brazil, two private institutions and one public institution.

The teachers were chosen by the principals' testimonies that considered the teachers indicated with successful practices in Math in those schools. The method used to choose the teachers was the interviewed technique (oral method). Each teacher's interview lasted about two hours, it was done with a pre-elaborated questionnaire. The interviews were recorded and after they were transcribed.

All the chosen teachers were graduated in Mathematics, most of them were postgraduate and worked about forty hours per week. All of them had, in that epoch, about thirty years of experience.

The pedagogic practices of Math teachers were analyzed, in the sense of comprehend as historic practices, permeated as conception about the ways to teach and learn Math, the options for some methods, some teachers behavior considered more favorable to stimulate and evaluate students' learning, the choice of the didactic resources considered more appropriated to learn the Math concepts.

\section{Teachers Conceptions about Mathematics and Its Teaching}

This topic focuses on one of the dimensions considered successful inside the whole study of Berticelli (2012) where we can find the other four dimensions that were also considered to characterize the successful practices of the interviewed teachers. Here they are: Didactic resources, Learning activities, Relationship between teacher and student, Motivation practices of the students and Evaluation practices.

The PCNs suggests that the teacher must be able to identify the main features of the Math as a science, its methods of teaching, its ramifications and applications. To this it is necessary that the teacher has clarity of his own conceptions about the Math, once that the practices in the classroom, the pedagogic choices, the definition of the teaching objects and contents and the evaluate forms are closely linked to his conceptions.

To analyze the teachers' interviews we sought theoretical foundation in authors that study the teachers' formation, as Thompson (1997), Charlot (2003), Cunha (1989), Freire (1996), Brougère (1998), Nóvoa (2009), Tardif (2010), Ribeiro (2011).

The researchers have showed that the relationship between the performance and the knowledge of Math teachers have focused only in the domain of the Math content. To them a little attention has been given to how the knowledge is integrated to the pedagogic plan and to the pedagogic action of teachers. We believe that the structure of the content and the way as it is thought is extremely important to the students learning and

${ }^{3}$ The epoch that this paper was done, it was not mandatory to have the verdict of the Ethical Committee in that University, that why we have the authorization letters from the interviewed teachers to use the information. 
to their actions about learning and the content.

There are a lot of factors that interact with teachers' Mathematics conception and it's teaching, affecting their decisions and behaviors, including beliefs about teaching, that are not specific of the Math teaching, showing that the Math and its teaching is a complex relationship, and deserves a good look.

OneinterviewedteacherALBR ${ }^{4}$ (2011) said that the relationship with the students is strictly about the Math contents and its teaching. However for the teacher IB (2011), another teacher interviewed, "we end up becoming mother of students" (our translation). What can be seen is that teacher's beliefs, views and preferences about the Math and it's teaching, play a significant role in the formation of characteristic patterns of teacher's behavior and especially about the teaching practice.

The way how you see/understand the Math has strong implications in the mode in how it is understood and practiced the Math teaching and vice versa. The teacher who concepts the Math as an exactly science, logically organized and no-historical or totally ready and unfinished, certainly will have a pedagogic practice different from that conceives as a living science, dynamic and historically been built by men, attending to certain interests and some social needs.

In the same way the teacher who believes that the student learns Math by the memorization of facts, rules or principles transmitted by teacher or by the exhaustive repetition of exercises, will also have a different practice from the one who understands that the student learns building the concepts from the reflex actions about the materials and activities, or from the problem-situation and problematization of Math knowledge.

Another teacher that participates in the investigation, MSR, talked about the students' freedom to participate in the class and make questions. To her, it is very important and necessary the students make questions, because it can show if he is understanding or not. She also said that the students can make the same questions and she will explain how many times it will be necessary, and in different ways, because she believes that it is necessary to repeat the explanation to the students to help them comprehend. To Cunha (1989, p. 99) the teacher leads students to "action, curiosity, critical reflection, demanding questioning, the restlessness and uncertainty".

The teachers interviewed also believes that the homework has an important role in learning, that's why they demand to give activities as homework every day and always to correct with the students. They believe that this can favor to develop the habit of the daily study of the students. They said that is important to renovate the activities and do new exercises every year according to the classes' necessity. They consider that the Math learning happens when the student does exercises. To them is not possible to learn Math reading, so they give a lot exercises to the students practice. They look for different exercises, problems and seek to create situations where the student can produce the knowledge.

Another factor considered as a good practice in the class is the collective production

${ }^{4}$ The teachers' names will be marked by acronyms to maintain the privacy and anonymity of participants. ${ }^{5}$ This teacher believes that the relationship with the students goes beyond the didactic situation. She feels like mother of the students. 
by the students. The knowledge produced collectively is an activity that can favor a lot the student's learning. In this case, to the teachers, it is necessary to the teacher pay attention in the students to see who is really working and who is pretending. Who understood the subject or not. This practice allows to the student to have active voice and to use the space of the class to produce the knowledge. To Cunha $(1989$, p. 25), that encourage the knowledge collective production, the student has active voice and uses the class space to participate, "the verbal environment of the classroom is the key to a participatory class and even creative (...). The valuable is to do the students speak and interfere in the learning and teaching process".

Another characteristic of their classes is the activities planning. To them the classes planning is very important to the class be succeed. They are not used to using the same material from one year to the other, because the students change and their necessities too. They don't believe that one teacher who has twenty years of experience really has twenty years of experience, if he does always the same thing in the same way, he has one year of experience and repeated the rest of the life.

The teachers also said that the experience can give to the teacher the capacity to make changes in the classes planning according to the classes' answers. If some plan didn't work well, the teacher immediately needs to change the situation and adapt to the class's necessity. They called this jogo de cintura or in English the skill of being flexible. It is the teacher's ability to change, adapt, transform the methodologies as the students needs. To Tardif (2010) part of learning and teaching process is the teacher mobilizes a lot of knowledge, reusing in the work toadapt and transform by and to the work. It includes "reflexivity, recovery, reproduction" of what known to do, in order to produce his own professional practice.

To the teachers is very important they trust in their own methodology, and try to make the students change their opinion about the Math. To them when you get to do the student that didn't like the subject, end at least, accepting by the teacher's influence, it shows that the teacher is in the right way and he is getting to change the student's mind.

To trust in the own methodology is necessary the teacher keeps himself in constantly formation, always studying, looking for new ways for teaching, considering that the knowledge is in a process of building. The interviewed teachers said that they believe they can't stop studying and looking for new knowledge.

In the teachers' conception, to the learning happens the teachers must have a good relationship with the students. To them a small look to the student can make total difference. The student needs to fell that the teacher is looking to him, caring with him, and worried about his learning. To the teachers the student just learns when he likes and understands the subject. So, it is necessary to the teacher create situations to aware the students taste for the Math and possibility the learning.

\section{Conclusion}

In a successful pedagogic practice, the relationship that the teacher keeps with his sub- 
ject, the Math, is essential in the teaching and learning process. In the teacher's deposition, it was possible to see that when the teacher said he likes his subject, he suggested to be important to pass this "taste" to the students. This concern is revealed in the describe that value actions like: encouraging students' participation, stimulating the students' questions, stimulating to create the daily studying habit, encouraging the student to produce the Math knowledge.

A successful practice in Math is marked by the exercises practice. The teachers believe that Math is learned doing exercises. They consider that the more exercises, the more likely to learn. They also talked about the necessity to innovate the planning, the necessity to work in groups, the collective knowledge construction.

Another characteristic of the successful practices is the investment in the professional development. It is important to the teacher to reflect about his practice, renovate and innovate his actions, considering that the teacher develop this ability of changing, adapting and transforming the methodology as it is necessary.

The reports indicate also, that in a successful practice the teacher needs to have the sensibility to feel the student. It means to know better the student and to perceive from his behavior in the class, from his view, from his actions, if he is understanding or not. In this case is fundamental the ability to the teacher explains the same subject in different ways, with different methodology, allowing the students' learning.

The successful education is based in practice epistemology and is comprehended as process of act and thinks rightly in the classroom, to take wise decisions before the unexpected and to choose alternative ways to transmit the subject and to interact with the students.

\section{References}

Alves, A. J. (1991). Planning Qualitative Research in Education. Research Notebooks, No. 77, 5363.

Berticelli, D. D. (2012). Successful Practices of Mathematics in the End of Elementary School. Dissertation (Master Degree in Education) - Graduate Program in Education, Curitiba: Catholic University of Paraná, 169 p.

Bogdan, R. C., \& Biklen, S. K. (1994). Qualitative Investigation in Education: An Introduction to Theory and Methods. Porto: Editora Porto Editora.

Brougère, G. (1998). Gameandeducation. Translationby Patrícia Chittoni Ramos. Porto Alegre: Artes Médicas.

Charlot, B. (2003). The Subject and the Relationship to Knowledge. In R. L. L. Barbosa (Ed.), Teacher's Training: Challenges and Prospects (p. 503). São Paulo: Editora UNESP.

Chervel, A. (1990). History of School Subjects: Reflections on a Research Field. Teoria \& Educação, No. 2, 177-229.

Cunha, M. I. (1989). The Good Teacher and His Practice. Campinas, SP: Papirus.

Freire, P. (1996). Pedagogy of Autonomy: Necessary Knowledge for Educational Practice. São Paulo: Paz e Terra.

Nóvoa, A. (2009). Teachers: Future Images in Thepresent. Lisboa: EDUCA.

Patton, M. (1986). Qualitative Evaluation Methods. Beverly Hills, CA: SAGE Publications. 
Ribeiro, C. M. (2011). The Importance of Knowledge of the Mathematical Content in Teaching Practice of a Teacher: Discussing an Analysis Model. Zetetiké-Mathematics Education Journal, 19, 71-102.

Richardson, R. J. (Andco-Authors) (1999). Social Research: Methods and Technics. São Paulo: Atlas.

Santos, B. S. (1989). Introduction to a Postmodern Science. Rio de Janeiro: Graal.

Tardif, M. (2010). Teaching Knowledge and the Professional Qualification (11 a ed.). Petrópolis, RJ: Vozes.

Thompson, A. G. (1997). The Relationship between Conceptions of Mathematics and Mathematic Teaching of Teachers in Teaching Pedagogic Practice. Zetetiké-UNICAMP, 5, 11-44.

Zeichner, K. M. (1993). Reflective Teacher Education: Ideas and Practices. Lisboa: Educa.

Submit or recommend next manuscript to SCIRP and we will provide best service for you:

Accepting pre-submission inquiries through Email, Facebook, LinkedIn, Twitter, etc.

A wide selection of journals (inclusive of 9 subjects, more than 200 journals)

Providing 24-hour high-quality service

User-friendly online submission system

Fair and swift peer-review system

Efficient typesetting and proofreading procedure

Display of the result of downloads and visits, as well as the number of cited articles

Maximum dissemination of your research work

Submit your manuscript at: http://papersubmission.scirp.org/

Or contact ce@scirp.org 